\title{
Lidství, věda a svět jako konstituenty Evropy a jejich proměna ve 20. století. Př́klad marxistické pedagogiky
}

\section{David RYBÁK}

\begin{tabular}{l} 
ARTICLE INFO \\
\hline Article history: \\
Received 9 January 2020 \\
Accepted 27 October 2020 \\
Available online 31 \\
December 2020 \\
\hline Keywords: \\
marxism-leninism, marxist \\
pedagogy, metaphysics, \\
production \\
\hline D. Rybák \\
Univerzita Karlova \\
Pedagogická fakulta, \\
katedra občanské výchovy \\
a filosofie \\
Magdalény Rettigové 4 \\
11639 Praha $1 \bullet$ \\
Česká republika \\
david.rybak @ pedf.cuni.cz
\end{tabular}

\begin{abstract}
Humanity, science and the world as constituents of Europe and their transformation in the $20^{\text {th }}$ century

This article tries to highlight main characteristics of the metaphysical frame of Marxist pedagogy. At first, it is important to see that the concept of ideology alone (in the question regarding totalitarian ideologies) presupposes a very specific metaphysic, i.e. metaphysic of the representing subject and subject of representations-ideas. In such a metaphysic a specific decision about humanity of man as well as worldliness of the world is introduced in the form of re-presentation and objectifying. How the humanity of man is understood? Is there not, under the political rhetoric of ideologies (totalitarian and not-totalitarian) a deeper common ground hidden, as our reference to the metaphysics of the subject was supposed to indicate? Insofar as upbringing in the European tradition has a sense of bringing man up to his own humanity, there is an implicit concept of human being in every concept of education. And insofar as man is not only an object in the world but also the "subject for the world" (Husserl), every such concept is arising from the correlation man-world. We would like to look more closely at the conditions of this correlation man-world in $20^{\text {th }}$ century.
\end{abstract}

„[...] vychvalovaná a uctívaná STRANA, tento konglomerát pohanské církve a policejnè--byrokratické šedi, existuje a jedná jako nepoučitelná zatvrzelost nerozumu a zaslepené arogance. Proto se její panství muselo dřvive či později zhroutit. Dnes na misto této zkrachované instituce nastupuje ona instance, která se s nemenši aroganci a zaslepeností vydává za normalitu, odpovidající lidské přirozenosti, za konečně nalezený a ve společnosti uplatňovaný dějinný rozum, jehož fungování zajistí prosperitu a svobodu. Touto instancí je TRH, který sám sebe považuje za nejvyšši a rozhodujicí realitu."

Karel Kosík

\section{Úvod}

Je tomu již téměř deset let, co se na stránkách časopisu Pedagogika rozvinula diskuse ohledně možností př́stupu k marxistické pedagogice a pedagogům, která se stala výchozím bodem pro 
další bádání (srov. Mareš, 2010, Průcha, 2010). ${ }^{1}$ Jakým způsobem přistoupit $\mathrm{k}$ nedávno minulé pedagogice a pedagogům (z nichž mnozí dosud žijí a působí), aniž bychom k nim přistupovali předem jako $\mathrm{k}$ vyř́zené věci?

$\mathrm{V}$ následujícím příspěvku vycházím především $\mathrm{z}$ Husserlova fenomenologického projektu zkoumání žitého světa. Nemohu ovšem v tomto textu rozvinout metodický rámec tohoto rozlišení, jak je proveden vHusserlově nedokončené knize Krize evropských věd a transcendentální fenomenologie. Pro účely tohoto textu postačí, uvědomíme-li si, že kromě půdy historické fakticity je možné zkoumat též historické apriori (srov. Husserl, 1996, s. 4046), k němuž patř́ též způsob, jak v daném dějinném čase rozuměli lidé svému světu a sobě samým. A v tom je opět obsaženo, že je možné prozkoumat příslušný dějinný svět s ohledem na to, jak je v něm rozuměno smyslu a způsobu bytí. Tak např́klad jistým způsobem je rozuměno smyslu bytí ve světě, který je rámován křest’anskou vírou v boží zjevení a stvoření, tedy ve světě, v němž se vše ukazuje jako stvořené a odkazující na první příčinu. A jiným způsobem zase ve světě, v němž výchozí půdou je moderní subjektivita, objev půdy vědomí, vůči němuž vše jsoucí vystupuje se smyslem objektivity. Rozumění není přitom závislé na mínění či výběru jednotlivého člověka. Je naopak apriorní $\mathrm{v}$ tom smyslu, že patří k samotnému situování se do srozumitelného světa.

Husserlovu fenomenologii využívám zde speciálně pro dotázání smyslu světa a lidství člověka, jak funguje uvnitř marxismu. Zajímá mne v tomto textu dějinnost, a to jako souvislost konstituce a zatemňování a převracení původního živého smyslu základních motivů světa a lidství. Tato souvislost patří k Evropě podstatně, ${ }^{2}$ nebot' vyzdvižení smyslu toho, kdo je to člověk a jeho svět, jako kdo tedy má být vychováván a vzděláván, patří ke specifické tradicionalitě Evropy. Zajímají mne zde predpoklady toho, jak je rozuměno světu, lidství člověka a potažmo výchově a vzdělávání.

Cílem tohoto textu tedy je rozvinutí následujících otázek: Jaký metafyzický rámec - čili jaký smysl bytí - panuje jako řídící intence v marxistické pedagogice? A jak je v této odpovědi na otázku smyslu bytí konstituována soupatřičnost lidství a světa? Jak konečně tato odpověd' zapadá do širšího projektu našeho, tedy novověkého světa? Jedná se o to porozumět výpovědím výpovědím marxistických pedagogů $z$ metafyzického rámce, $z$ více či méně implicitního, $\mathrm{v}$ tradici zděděného vyložení smyslu bytí, který skrze ně prochází jako řídící intence.

Zohledněním společného světa získáváme půdu, na níž je možné přistoupit k marxistickému a jakékoli jiné podobě projektu novověku uvnitř evropské tradice. Je to tentýž svět, totiž svět vbudovaný do rámce metafyziky představujícího vědomí a v tom implikovaných idealizujících konstrukcí, co mají společné at’ už jakkoliv rozdílné politické systémy novověku.

\footnotetext{
${ }^{1}$ Na tuto diskusi se odvolává též výzkumná (dvoj)monografie badatelů Jiř́ho Zounka, Michala Šimáněho a Dany Knotové. Srov. Zounek, Šimáně a Knotová, 2017.

${ }^{2} \mathrm{~V}$ tomto smyslu je tato studie zvláštním rozvinutím fenomenologie světa, které jsem souvisleji provedl jinde. Srov. Rybák, 2019. K fenomenologii světa (Weltphänomenologie) srov. Held, 2018.
} 
Zvolená interpretující perspektiva se zdá vykazovat značné nedostatky: všechny krávy v ní jsou černé, totiž všechny perspektivy na půdě světa vyjdou potom na stejno. Jako by nebyl rozdíl mezi tím, žiji-li ve „svobodě a demokracii“ či žiji-li ve fašistickém či nacistickém režimu. Taková námitka ale přehlíží, že teprve zohledněním paradoxní ${ }^{3}$ perspektivy celku světa jednotlivé perspektivy vyniknou právě jako perspektivy. Nic nebrání tomu, vyznačit též specifické charakteristiky, které patří k tomu či onomu postoji uvnitř společného světa. A opačně, závažnou konsekvencí zmíněného objektivismu a redukce vědění na expertní obory je jistá deficience $\mathrm{v}$ teoretickém záběru, týkající se mimo jiné př́stupu k věcem lidským. Nebot' zdánlivá neutralita expertního vědění vưbec není nevinná, nese s sebou již jisté rozvržení světa a jistou odpověd' na to, v čem spočívá lidství člověka.

\section{Metafyzika produkce}

Jaký je to metafyzický rámec, do něhož je zarámována marxistická pedagogika? Tento rámec můžeme souhrnně označit jako metafyziku produkce, která je rozvinutím metafyziky subjektu $\mathrm{v}$ její dějinnosti. Ale tato charakteristika nemůže být důvodem $\mathrm{k}$ odmítnutí této podoby pedagogiky. Při vší své deformující politizaci byla marxistická pedagogika živou větví pedagogické vědy, měla svůj vývoj, své objevy a cenné ideje, své neprobádané horizonty a možnosti a stejně tak byla schopna rovnocenné a kritické diskuse s ostatními teoretickými východisky a proudy. Nelze ji tedy jen tak odmítnout ve jménu nějaké jiné pozice. ${ }^{4}$

$\mathrm{V}$ tom, co je zde předkládáno, se nejedná primárně o marxistickou pedagogiku a vůbec nedávnou minulost, ale o náš prítomný postoj k ní a k nám samotným, o nevyjasněné teze, které v nás fungují. Instinkt „morálního“ stanoviska, reaktivní kritiky marx-leninské ideologie je oprávněný, pokud poukazuje na to, jak se jisté ideje stávaly uvnitř politického boje jeho pouhými instrumenty. Na to, jak myšlení bylo uzavřeno do železného rámce předpokladů a dogmat a tento rámec nebylo možné zpochybnit. Pluralita mínění a možnost jejich vyjádření byla zablokována, a tak se i cenné objevy, které lze nalézt u tzv. „klasikư“, převrátily v dogmatické fráze. ${ }^{5} \mathrm{Na}$ druhou stranu by ale zmíněné odsouzení nemělo zakrýt to, že též naše vlastní prŕítomnost není nevinná, ba že i v ní se můžeme setkat s formami totality, které jsou o to nebezpečnější, že fungují jako součást hladkého chodu systémů (ekonomických, sociálních, evaluačních, sledovacích atd.). Smyslem tohoto textu tedy není odsuzování, tím méně oslavování marxistické pedagogiky. Cílem této studie je v rámci omezeného prostoru stručně zachytit některé podstatné charaktery konstitutivní pro metafyzický rámec marxistické

\footnotetext{
3 Paradox spočívá v tom, že theóretická perspektiva celku není žádnou perspektivou, ale je získaná jenom v distanci myšlení, v pozastavení vykonávání (naivního) souhlasu s tezí světa.

${ }^{4} \mathrm{~V}$ této tezi, stejně jako v hodnocení marxistické pedagogiky, souhlasím s Jarmilou Skalkovou (Skalková, 2004, s. 23-25).

${ }^{5} \mathrm{O}$ tendenci marx-leninské filosofie k dogmatismu srov.: „Po únoru 1948 se sice vytvářely vnější podmínky pro její profesionalizaci, na druhé straně byl však její rozvoj nadále bržděn a v některých obdobích i prakticky vyloučen stálou stranickou reglementací, podporující i působení vlastních vnitřních dispozic marxisticko-leninské filozofie k dogmatismu (srov. např. převládající apriorní pojetí marxisticko-leninské fillozofie jako jediné vědecké a pokrokové filozofie, s nadřazeným postavením vủči vědě, její kladení do nesmiřitelné kontradikce se všemi dalšími filozofickými proudy a směry jako filozofiemi „buržoazními“, „nevědeckými“, „reakčními“, „překonanými““ atp.).“(Bayerová a Gabriel, 1995, s. 116).
} 
pedagogiky, pokud je vázána oficiální marx-leninskou doktrínou států tehdejšího východního bloku.

Ve svém zamyšlení o dvacátém století jako době krize modernity píše Jaroslava Pešková o poválečném nadšení, neseném osvícenskou důvěrou $\mathrm{v}$, ,dělatelnost dějin“ a $\mathrm{v}$ reálnou možnost, že ,život na zemi předěláme“ (Pešková, 2000, s. 44). Právě tato víra v dělatelnost dějin, implikující sebevyložení člověka jako spontánního subjektu, jehož spontaneita spočívá v charakteru: ,skrze formu představování určovat svět a jsoucí‘, je metafyzickým základem nejenom tzv. marxismu-leninismu, ale zachycuje též specifický projekt dělání světa člověkem jako prolongace a variace novověkého projektu. ${ }^{6}$ Bylo by možno namítnout: ale existuje, a to právě ve 20. a 21. století, celá řada kritiků tohoto osvícenského ideálu. Ale zde nepojednáváme o ideálech, nýbrž o zpưsobu bytí novověkého člověka, který si mj. rozumí právě z protikladu ideálního a reálného. Ještě silněji vyjádřeno: sebevbudování do systému idealizovaných vědeckých konstrukcí a v tom do technologického aparátu produkce je způsobem dějinného bytí člověka. Pro připomenutí - nejedná se o jednotlivé perspektivy na půdě světa, ale o společnou půdu, na níž se tyto perspektivy, at' protichůdné, či souhlasné, konstituují.

Všechny tzv. ideologie musejí mít při vší disparátnosti a vzájemné neslučitelnosti něco společného, společnou půdu, na níž se setkávaly uvnitř dvacátého století a v jistém smyslu stále setkávají i ve století jednadvacátém. Touto půdou je uvnitř evropské dějinnosti svět rozuměný a vyložený jako planeta (Novák, 2011, s. 95-100), jako prostor, k jehož smyslu patři intence dobývání a ovládání, která je uvnitř dějinnosti Evropy uskutečněna právě ve dvacátém století. $\mathrm{V}$ tomto smyslu světové války jako války o svět jsou zároveň děním, v němž se svět proměňuje na planetu, na totálně ovládaný a kontrolovaný prostor. Skrze reprezentaci soutěže dvou mocenských bloků se ve dvacátém století prosazuje nutnost jako nereprezentovatelná strana dějinného vyplnění intence ovládnutí a přisvojování si př́rody. Jinak řečeno, smyslem všech ideologických reprezentací je vbudování člověka do systémů účinnosti.

Novověký člověk, resp. soupatřičnost ,člověk a svět‘, rozumí sobě samému jako subjektu vztahujícímu se k souvislosti světa a př́rody ve smyslu objektivity (Palouš, 2010, s. 39). O nereprezentovatelnosti při charakteristice metafyzické půdy mluvím proto, že to, co je viditelné, je totožné s reprezentovatelností, tj. s řetězy reprezentací skrze sebejistotu se určujícího subjektu. S konstitucí této půdy subjektivity dochází též k proměně smyslu vědění. To přestává mít povahu theória či contemplatio, ale je smysluplné ze souvislosti sebeurčování: je to sebejistota myslícího já, která skrze určování objektivity potvrzuje sebe samu (srov. Palouš, 2005, s. 60-61). Smyslem vědění je v tomto rámci: učinit lidi ,jakoby pány a vlastníky př́rody“ (Descartes, 1992, s. 45). V naznačeném základním horizontu je marxistická pedagogika zasazena, čili taktéž výchova a vzdělání ${ }^{7}$ jsou myšleny z tohoto

\footnotetext{
${ }^{6}$ Obdobně směřuje ve svém uvažování i Radim Palouš, když ukazuje, že to, co nazývá totalismem, nemá pouze politický charakter, ale nese $\mathrm{v}$ sobě novověkou intenci „s absolutní platností ... vyčerpat rozvrh dalšího chodu dějin“" (Palouš, 1996, s. 9).

${ }^{7}$ Klaus Schaller ukazuje na disociaci vědění a vůle, která na půdě metafyziky vědomí vedla $\mathrm{k}$ disociaci výchovy a vzdělání: „Výuka, která jde za pravdou, člověku již neříká, že se má pravdy při svém mluvení a jednání zastat;
} 
projektu ovládání prŕŕrody člověkem a - nakolik též člověk je součástí přírody - člověka člověkem. Výchova je pojata jako regulování psychických a fyzických procesů: „Pojmem vzdělání bychom měli rozumět výsledek všech procesů a činností zaměřených na utváření člověka" (Váňa, 1963, s. 64).

Marxovo myšlení vychází z dědictví neseného evropskou tradicí. Metafyzika produkce, která stojí v základu marxismu-leninismu, je pokračováním teologie. V novověké metafyzice subjektivity je vertikální teologická souvislost creatio, tvoření světa, vnořena př́mo do vztahu subjekt-objekt. Subjekt je sebeprodukce ve formě udržování identity se sebou skrze negativitu: uskutečňování se skrze negativitu předmětnosti. Marx přesně vyjádřil tuto proměnu novověké metafyziky: „Jestliže dříve bohové bydleli nad zemí, stali se ted' jejím středem.“ (Marx, 1978, s. 140). Creatio staré metafyziky a perceptio nové metafyziky je nahrazeno productio: absolutní půdou není již stvoření, ale koloběh člověk-př́roda, neustálé sebeprodlužování tohoto koloběhu. Přitom ale idealizující předpoklady obsažené v obou předchozích podobách metafyziky zůstávají nedotázány. Tak ústí Marxovo myšlení přece jenom do opakování téhož schématu sebeurčujícího subjektu.

Zároveň ale Marxovo myšlení znamená již zamyšlení nad mezemi souvislosti sebeurčování a přivlastňování. Marx je jeden z prvních myslitelů novověku, kteří si činí problémem systém zprostředkování, skrze který se sebeurčování a přivlastňování odehrává, a to s ohledem na člověka, který se nutně v tomto systému stává též pouhým prostředkem. Ve svých analýzách se snaží sestoupit k nereprezentovatelné základně, kterou je sebeprodukování, v němž člověk je v posledu příčinou i cílem sebe sama. Jde tedy o to, aby si člověk přisvojoval svět a sebe sama lidsky, ne aby ze sebe sama dělal pouhý prostředek přisvojování. Považuji za důležité zdůraznit, že problém lidského osvojování nebyl doposud uspokojivě vyřešen.

V souvislosti s problémem lidského přisvojování Marx znovu objevuje v novověkých podmínkách motiv školy (scholé). Nebot' základem lidského osvojování si světa je pro Marxe osvobození lidského času osvobozením se od mašinérie výroby jejím ovládnutím. Tento čas již nebude časem objektivovaným v idealizaci ekonomického odcizení, v posledu vyjádřené penězi, ale volným časem (Freizeit), v němž člověk bude produkovat sebe sama svobodně. Jenomže Freizeit je myšlen v kruhu produkce, struktura vědomí a sebevědomí je zde zachována. Pouze namísto hegelovského k-sobě-přicházení sebevědomí zde máme bytí, resp. sebeprodukci člověka, který ovládl podmínky přisvojování si světa a sebe sama. Volný čas je volným časem jenom uvnitř kruhu sebeafirmace, čili žádným volným časem ve smyslu scholé není. Ono ,lidsky si přisvojovat ' ústí do totálního ovládání, jinak řečeno, ovládnutí produkce je možné jenom konstitucí totality, totálního cirkulu, v němž se ovládající stane též ovládaným, a to ve všech sférách sfého života.

Zmínil jsem se již o tom, že skrze dějinný projekt, v jeho vyplnění je stále více viditelná jeho nereprezentovatelná strana, totiž nezamýšlené důsledky, které jsou pro plánující subjektivitu neviditelné. Nereprezentovatelnost souvisí s tím, co můžeme označit jako problém

a tu se stalo potřebným vyučovat etice zvlášt’. Tím se výchova jako historický jev stává školením vůle“ (Schaller, 1993, s. 36). 
ovládaného ovladatele. ${ }^{8} \mathrm{~V}$ dějinnosti novověkého projektu svobody skrze zpředmětňování dochází neustále znovu k tomu, že prostor ovládání je vytěžen, vyjádřeno Marxovou terminologií: je vtažen do prosté (sebe)reprodukce. Přestává tak dostačovat, působit uvnitř soustrojí ovládání. Další expanze je možná jenom tak, že jsou objeveny nové prostory vytěžení, potažmo nové způsoby zpředmětňování. V proměně světa na planetu přestává uvnitř novověké dějinnosti, tj. uvnitř vyplňování novověkého projektu ovládání prrírody, planetární prostor dostačovat.

Aby bylo možné novověký projekt prolongovat, obrací se různé způsoby ovládání na člověka, ovladatele samotného. ${ }^{9}$ I ten musí být ovládnut, přizpůsoben podmínkám systému ovládání, a to tak, že způsoby lidského osvojování světa jsou zvládnuty jako momenty lidského bytí čili cirkulu produkce: „Podstata věci je v tom, aby nejen duchovní potřeby nezaostávaly za materiálními, ale aby také osobní potřeby odpovídaly potřebám společnosti.“ (Cipro, 1973, s. 270). Způsoby osvojování světa jsou určeny jako obsahy výchovného působení: „Obsahem výchovného pưsobení by potom měly být základni zpưsoby, kterými se člověk zmocňuje světa i sebe sama, tj. duchovní a duchovnè praktické způsoby osvojování světa." (Kodýtková, 1968, s. 15). ${ }^{10}$ Výchova a vzdělání přitom významově vyvstávají jako klíčové nástroje i momenty produkce, či jak to vyjadřují marxističtí pedagogové, jsou nástroji ,potřeb socialistické společnosti““. ${ }^{11}$ Tak upozorňují marx-leninští pedagogové, že učitelé již na základních školách jsou předpokladem „převýchovy“. Tato převýchova má jednak negativní cíl zbavit se buržoazního způsobu formování vědomí lidí, jednak pozitivní cíl, totiž vytvořit „socialistické uvědomění،, které je samo odrazem sociálního vědomí objektivní reality (Galla a Sedlář, 1979, s. 4-5). Tak i svoboda člověka je určena z cirkulu produkce, tedy ze společenských potřeb a společensky určené nutnosti: „Svobodný je v naši společnosti ten člověk, který

\footnotetext{
${ }^{8}$ Mnozí marxisté si alespoň zčásti byli vědomi limitů technických řešení. Tak například na samém sklonku socialistického režimu vidí Jarmila Skalková zdroje přitažlivosti novějších teoreticko-pedagogických koncepcí právě $\mathrm{v}$ jejich položení problému moderní techniky: „Racionální jádro a nepochybně $\mathrm{i}$ jeden ze zdrojů přitažlivosti podobných proudů je skutečnost, že postřehly, i když často $\mathrm{v}$ jednostranné a deformované podobě, významné reálné problémy a hledají jejich řešení. Zdưraznily význam orientace na člověka, poukazují na rozpornost důsledků moderní techniky, která sama nemůže vyřešit mnoho lidských problémů. Odhalují rozpor mezi pokrokem vědy a techniky, jejich pronikáním do všech sfér života a skutečným rozvojem člověka.“ (Skalková, 1989, s. 243).

9 Připomínám, že popsaná souvislost nemá místo v historickém čase, ale patří do samotného novověkého projektu ovladatelství, v němž se neustále opakuje.

${ }^{10}$ Za pozornost stojí dva texty od Dagmar Kodýtkové z konce šedesátých let, které vyšly v časopise Pedagogika. Kodýtková v té době působila na pedagogickém oddělení Pedagogického ústavu Jana Amose Komenského (za tuto informaci děkuji doc. Isabelle Pavelkové). Jednak se inspirují Kosíkovou Dialektikou konkrétního (což by v dalších normalizačních letech po Kosíkově vyloučení z ÚV KSČ již nebylo možné), jednak propojují pedagogickou a filosofickou rovinu předpokladů, z nichž marxistická pedagogika vychází. Karel Kosík se v otevřenější reformní atmosféře druhé poloviny 60 . let objevuje jako důležitý zdroj i u dalších teoretiků a filosofů zabývajících se pedagogikou (Kozel, 1967, Kučerová, 1969).

11 „Obsah vzdělání se přizpůsobuje třem základním činitelům: 1. potřebám socialistické společnosti, jež jsou vyjádřeny v požadavcích, které socialistická společnost klade na život a práci svých členů, tj. na jejich práci, rodinný a společenský život a výchovu dětí, na zdraví lidí, na způsob života ve volném čase a na další vzdělávání; 2. vývoji společenského poznání a společenské praxe; 3. rozvoji a možnostem žáka. ... Obsah vzdělání odráží všechny tyto činitele. Vychází především z potřeb společnosti a z vývoje poznání a praxe. Ty se přeměňují v obsah vzdělání na základě formulovaných cílů, jež berou v úvahu i dané podmínky výchovně vzdělávací práce a prostředky, které jsou k dispozici“ (Pařízek, 1984, s. 10).
} 
dobrovolně morálně jedná, sám si ukládá omezení společensky nutná a aktivně plní požadavky společensky nutné، (Fiala, 1964, s. 444).

Je třeba zohlednit též převrácení smyslu, který náleží k transformaci statutu Marxových teoretických analýz. Tím mám na mysli zohlednění rozdílu mezi Marxovými analýzami produkce a jejich proménou na (oficiální) politickou doktrínu, která se má uskutečnit. ${ }^{12}$ Teprve v této proměně nabývají Marxovy analýzy charakter metafyzicko-teologické nauky, metafyziky produkce, jejíž pravdou a subjektem je komunistická strana (Kojzar, 1962, s. 5645). Řeč, a to i teoretická, nabývá neustálého sebestvrzování a sebeposvěcování tohoto dějinného subjektu (Fidelius, 1998). ${ }^{13}$ Teoretické výkony se potom vepisují do tohoto základního rámce.

Ze spojení produkce a komunistické strany jako dějinotvorné síly, která umožňuje tuto produkci regulovat s cílem lidského zvládání a osvojování světa, plyne též specifický charakter marxistické teorie, totiž přesvědčení o nadřazenosti perspektivy marxismu-leninismu jako vyššího dějinného stanoviska. ${ }^{14}$ Nebot' podle marxistických teoretiků jedním z klíčových problémů novověkého projektu v jeho kapitalistické podobě je právě ,živelnost“ produkce, nezvládnutí produktivní síly v její totalitě. Ve výchovné souvislosti to vyjadřuje Dagmar Kodýtková: „Člověkem živelně vytvářené společenské bytí živelně ovlivňuje svého tvůrce. Společenské bytí tak, jako bylo člověkem vytvářeno v dosavadní lidské historii, bylo vytvořeno z hlediska uspokojení různých dílčích, jednotlivých dočasně dominujících lidských potřeb, ale nebylo tvořeno s cílem uspokojení takových potřeb, které postupně krystalizují ve stále silnější komplexní potřebu univerzálního rozvoje. Proto společenské bytí ve své dnešní podobě nepodporuje plně rozvoj člověka, ale naopak ho v mnoha ohledech brzdí a deformuje“ (Kodýtková, 1968a, s. 7).

\footnotetext{
${ }^{12} \mathrm{Z}$ hlediska dějin metafyziky je ale důležité připomenout, že tento předpoklad uskutečnění filosofie patř́ k Marxovi samotnému. Srov. Marx a Engels, 1956, zejm. s. 117, 407.

13 Př̌i vší omezenosti, v níž byla věda zatavena do specificky oficiální řeči, jejíž obsah by bylo možné charakterizovat jako metafyziku strany coby dějinotvorného subjektu, umožňovala též jistou svobodu. At’ už v podobě „vnitřního exilu“ či ,úlitby bohům“, kdy se pisatel zaštítil „,klasiky“ a v samotném textu byl již více či méně uvolněn $\mathrm{k}$ vlastnímu myšlení. K tomu viz článek Josefa Maňáka: „Atmosféra útlaku, strachu, persekucí a nesvobody, ale i výhod a preferencí svým stoupencům postupně vytvořila společenské klima, na něž si většina obyvatelstva zvykla. Lidé se uzavřeli do svého soukromí, mnozí odešli do emigrace, někteří se odhodlali k různým formám protestu, výjimečně i k ozbrojenému odporu, ale nejčastější obranou bylo švejkování.“ (Maňák, 2013, s. 387). Oficiální závazný rámec marxismu-leninismu jednak vytvářel celkový myšlenkový rámec, v němž se marxisté pokoušeli řešit problémy vědy a života, jednak ale umožňoval do sebe absorbovat též vnější myšlenkové rámce a impulsy. Často bylo přímo možné „,schovat“ pod marxistickou terminologii jinou problematiku a jiný způsob př́stupu. K tomu opět Josef Maňák: „Charakteristické pro vědeckou pedagogickou produkci v celém období bylo, že demokraticky smýšlející autoři se vyhýbali ideologickým tématům a zaměřovali se na ideově neutrální problematiku a na empirické výzkumy. Obvyklým rituálem bylo, že autor v úvodu statě odevzdal uctivou daň stranickým usnesením nebo Leninovu odkazu a dále pokračoval v řešení daného problému“"(Ibid., s. 389).

${ }^{14}$ Nejenom v pedagogické teorii nalézáme tato a podobná vyjádření: „Teprve marxismus-leninismus přináší obrat, když poukazuje na objektivní společenskou podstatu výchovy a její podmíněnost výrobními a dalšími reálnými faktory“ (Cipro, 1973, s. 268).
} 


\section{Člověk a výchova}

V právě nastíněném vyložení novověkého projektu je obsažen též jistý smysl toho, kdo je člověk. A pokud k výchově podstatně patří přivedení k lidství člověka, určuje tento sebe-výklad též smysl výchovy. Jak tedy rozumí lidství dvacátého století svému lidství? Z jakého projektu rozumí marxistická pedagogika tomu, kdo je to člověk? Člověk, resp. socialistický člověk, ${ }^{15}$ je určen ze svého vztahu ke světu a tímto vztahem je jeho „nejspecifičtější lidská schopnost", totiž „osvojovat si a měnit svět i sebe sama“: „Východiskem je marxistickofilosofické pojetí člověka jako předmětného tvořivého subjektu, jehož nejspecifičtější lidská schopnost je schopnost osvojovat si a měnit svět i sebe sama, schopnost vědomého vytváření sama sebe prostřednictvím své činnosti a jejích výsledků.“ (Kodýtková, 1968b, s. 888). Tak je zdůrazňována v marxistické pedagogice složka aktivního a angažovaného př́stupu ke skutečnosti (Kozel, 1967, s. 68) jako jeden z úkolů marx-leninské výchovy (Semrád, 1977, s. 658).

Mluvili jsme již o základním metafyzickém rámci (sebe)produkce člověka. Klíčovou roli v procesu (sebe)produkce člověka hraje práce (Grulich, 1982, s. 654). Práce je způsobem, jak si přivlastňuje člověk sám sebe ve své totalitě. Vytvářením „druhé přírody“ člověk zároveň poznává sebe sama (Kučerová, 1969, s. 18). Metafyzické schéma produkce slouží jako politické interpretandum prŕtomnosti a důraz na práci tak vystupuje jak v teoreticko-pedagogických úvahách, tak $\mathrm{v}$ politických programech. Tak zdůrazňuje programové usnesení $O$ těsném spojení školy se životem a o dalším rozvoji výchovy a vzdělání v ČSR přijatý ÚV KSČ 22.-23. 4. 1959: ,již ve škole musí být vyučování těsně spjato se životem, s prací. Musíme všestranně usilovat o to, aby práce jako tvůrkyně všech hodnot se postupně stala prvořadou životní potřebou všech našich lidí."16 Tento cíl měl být realizován naplněním zásady „spojení vyučování s výrobní prací žáků a posilování polytechnického vyučování““. ${ }^{17}$

Souvislosti ovladatelství, která konstituuje smysl moderního vědění a jednání, jsme se již věnovali. Doplňme v tomto smyslu pouze další charakteristiku lidství člověka dosahovaného marxistickou pedagogikou: „Tak jako socialistické uspořádání na jedné straně podmiňuje všestranné rozvinutí lidskosti, je na druhé straně všestranně vyvinutý člověk podmínkou existence komunistické společnosti, nebot' jedině takovýto člověk může být oním subjektivním činitelem, který dokáže plněji ovládat prŕírodu a vesmír a stát se pánem svých vlastních dějin“ (Engst, 1960, s. 574).

Pokud jde o cíl výchovy, je v marxistické pedagogice často formulován jako dosažení harmonické osobnosti (Váňa, 1960a, s. 689; Semrád, 1977, s. 658). Harmoničnost je většinou určována jako jednota subjektivních aspirací a objektivních potřeb (Baláž, 1977, s. 647) a osvojení si historicky na daném stupni dosažených způsobů osvojování světa a sebe sama: „Cíl výchovy — všestranný a harmonický rozvoj osobnosti — je možno realizovat jenom jako cílevědomé formování člověka prostřednictvím formování jeho vědomí, utvářením

\footnotetext{
15 „Socialistický člověk, kterého chceme vychovat z každého žáka, musí mít široké společenské zájmy, široké znalosti, hluboké socialistické přesvědčení podložené těmito znalostmi. Bez nových metod nedosáhneme tohoto cíle“ (Kolář, 1960, s. 684).

${ }^{16}$ Citováno podle Opata, 1981, s. 175.

${ }^{17}$ Tamt., s. 180. K problémům realizace programového usnesení srov. Urbášek a Pulec, 2012, s. 227-34.
} 
obsahu jeho vědomí, prostř̌ednictvím vědomého vytváření individuálního vědomí.“ (Kodýtková, 1968a, s. 6). ${ }^{18}$ Toto individuální vědomí má být vedeno „na úroveň celospolečenského chápání prrírodních a sociálně ekonomických zákonů, jevů a potřeb“ (Jelínek, 1965, s. 572) a tak má být zformován uvědomělý a aktivní budovatel komunismu (Loukotka, 1962, s. 131), určeného jako socialistický humanismus (Mácha, 1960; Engst, 1960; Váňa, 1961; Loukotka, 1962, s. 140-1).

Radim Palouš vyjasňuje novověkou proměnu školy v kontextu metafyziky ovladatelského postoje vi̊či př́rodě: ,Základní, potom střední a dnes i vysoké školství se považuje za výbavu pro budoucí pracovní život, pro zaměstnání, Ze školy nedělní se stala škola všedního dne, ze SCHOLÉ-prázdeň, uvolněnosti od imanentizovaných zřetelů pro transcendenci, se stává škola, imanentizovaná do obstarávatelského shonu, škola-zaměstnání jako jiné zaneprázdňující činnosti úzkoprsého života“ (Palouš, 1991, s. 62). Variantou této proměny je též marxistická pedagogika. Když Jaroslava Pešková reflektovala kriticky východiska marxistické pedagogiky, vyjádřila se lakonicky: „Harmonickou osobnost nelze vypěstovat jako šlechtěnou jahodu“ (Pešková, 2010, s. 150). Interpretuji tento poukaz ve smyslu již dříve zmíněného přesunu smyslu: pokud se nezeptáme na metafyzický rámec skutečnosti, veškeré pedagogické cíle i obsahy se do něho včleňují. To znamená, že smyslem cíle vychovat harmonickou osobnost není tato harmonická osobnost, ale právě produkovatelnost či konstruovatelnost (,vytvářeni“) jisté představy o člověku: „Cílevědomé vytváření takového obsahu individuálního vědomí, který by učinil osobnost maximálně schopnou účasti na konzumpci i tvorbě právě probíhajícího revolučního procesu, to je úkolem výchovy“ (Kodýtková, 1968a, s. 7-8). Podobně jako Jaroslava Pešková, též Radim Palouš promýšlí obecnější zasazení moderní pedagogiky a školy do novověkého ovladatelství: „Konstruktérské vědní úsilí se vrhá i na člověka samého: to obyčejné, přirozené, to poslední, co zbývá, je koncipováno jako neživý mechanismus. Člověk už není já v těle, jeho vlastní tělo se stává rejdištěm anonymních sil; už není událostí svého života co subjekt, nýbrž je objektem procesuálních proměn“ (Palouš, 1991, s. 61). Uvnitř metafyziky produkce je smysl lidství a potažmo výchovy srozumitelný ze situace vbudování člověka do souvislosti produkce a idealizujících konstrukcí. A právě z tohoto vbudování člověka do kruhu produkce a reprodukce, do něhož patř́ recipročně (marxističtí teoretici by spíše řekli: „dialekticky“) působící momenty technologických prostředků, resp. výrobních nástrojů, společnosti a člověka, je určen též smysl výchovy. Miroslav Cipro ${ }^{19}$ vyjadřuje koncízně tuto souvislost: „Jde o to humanizovat, respektive socializovat techniku a naopak technizovat člověka a společnost, její historii a její perspektivu“ (Cipro, 1973, s. 351).

Celý pohyb výchovy a vzdělávání je pojat jako proces řízení a sebeřízení člověka včleněného do vyšších systémů biologických, společenských, a nakonec do systému komunisticky

\footnotetext{
${ }^{18} \mathrm{Na}$ druhou stranu můžeme $\mathrm{v}$ otevřenějších šedesátých letech nalézt $\mathrm{i}$ jisté stopy kritiky takovéhoto spojení výchovy a ideálu harmoničnosti. Např́klad Hana Sychrová (1966, s. 660-1) upozorňuje na dějinnost a rozporuplnost moderního světa, v němž ideál harmonie realizovat není možné.

${ }^{19}$ Složitost hodnocení Miroslava Cipra a vůbec marxistických pedagogů vystihuje Josef Maňák, který ho na jedné straně zmiňuje jako „otřesný př́íklad stranické zaslepenosti“, na straně druhé ale uznává, že Cipro je též „autorem hodnotných publikací“ (Maňák, 2013, s. 389-90).
} 
řízeného, který se od ostatních systémů-subjektů liší vyšší úrovní sebeplánování a sebeř́izení (např. Grulich, 1982, s. 656). Předpokladem pro toto sebeřízení je poznání a zvládnutí př́rodních i společenských zákonů (Grulich, 1982, s. 659-60; Váňa, 1960, s. 686). K sebeřízení $\mathrm{z}$ hlediska výchovy patří problém výchovy $\mathrm{k}$ vědeckému „světovému názoru“ (Loukotka, 1962, s. 129-30), a to samozřejmě k tomu pravému, dialekticko-materialistickému (Semrád, 1977, s. 660) v konfrontaci s buržoazní ideologií (Baláž, 1977, s. 650).

Bylo by možno namítnout: významní marxističtí pedagogové, mezi sovětskými je to např́íklad Vasilij Aleksandrovič Suchomlinskij, upozorňují na to, že smyslem vzdělání není pouze pracovní uplatnění či zvyšování produkce, že k člověku patří též mravní, intelektuální, estetické ad. zájmy. Pouhý ohled praktického uplatnění nestačíi ${ }^{20} \mathrm{~V}$ tom ostatně marxistická pedagogika vysoko převyšuje mnohé dnešní budovatele kapitalismu. Anebo jinak řečeno, $\mathrm{v}$ tom si dnešní manažeři vzdělávání nezadají $\mathrm{s}$ tehdejšími kádry a plánovači. S uvedenou námitkou naprosto souhlasím, ale to nijak nezasahuje základní určení člověka z metafyzického koloběhu produkce. Naopak, v marxistické dialektice jsou všechny lidské potence do tohoto koloběhu (re)produkce vtaženy.

Stejně tak je možno namítnout, že ani horizont dělatelnosti člověka není v marxistické pedagogice přijímán naivně. Původní optimismus vytváření „,nového sovětského člověka“ je modifikován. V citovaném článku Dagmar Kodýtková varuje mimo jiné před optimismem „[ch]ápání člověka jako tvořivé bytosti, nadané vědomím (uvědomováním) světa i sebe a schopností kultivace svého okolí i svého nitra, by mohlo vést, a ve své primitivnější podobě také $\mathrm{v}$ minulosti skutečně vedlo ke dvěma krajnostem: $\mathrm{k}$ jistému přehnanému optimismu $\mathrm{v}$ teorii na jedné straně a $\mathrm{v}$ důsledku nedostatečných praktických výsledků výchovy (nedostatečných výsledků celé komunistické výchovy, nejen školní) k přehnanému pesimismu praxe na straně druhé“ (Kodýtková, 1968b, s. 889). Jenomže toto upřesnění nijak neopouští základní horizont dělatelnosti, čili metafyzický horizont vbudování člověka do struktur kruhu produkce zůstává nezměněn. ${ }^{21}$

\section{Namísto závěru: transformace dějinného subjektu strany $v$ trh}

Z dotázání horizontů marxistického projektu dělání dějin je snad viditelné, že tento projekt (a do něho zasazená marxistická pedagogika) je variantou novověkého metafyzického projektu. Stojí za to připomenout, že tento projekt neustále pokračuje. V tomto smyslu je

\footnotetext{
${ }^{20}$ Srov. např́íklad myšlenky sovětského pedagoga Suchomlinského: „Tam, kde sa na vedomosti pozerá iba z hl'adiska ich praktického použitia $\mathrm{v}$ budúcnosti, objavuje sa chladná, l'ahostajná kalkulácia, úsilie vole je podněcované nepěknými, ba niekedy nízkými pohnutkami, ako např́ílad, že cudzí jazyk třeba dobře poznat, pretože bez něho sa nemožno dostat' na nijakú vysokú školu, po absolvovaní strednej školy třeba íst' do výroby, přetože to je najkratšia a najbezpečnejšia cesta na vysokú školu atd'.“(Suchomlinskij, 1964, s. 7).

${ }^{21}$ V tomto prohloubeném smyslu je možné souhlasit s Dariuszem Stępkowským, když zmiňuje tř́i základní trendy marxistické pedagogiky: 1) ideologizaci, 2) sovětizaci a 3) pedagogizaci a tento třetí moment charakterizuje jako „víru ve všemocnost vzdělání a $\mathrm{z}$ toho vycházející přecenění možností a účinnosti pedagogických interakcí“. (Stępkowski, 2015, s. 5-6). K polské pedagogice říká Josef Maňák: „polští pedagogové si udrželi svobodnější postoj k západní produkci, např. francouzské a americké“. A vystihuje dále obecnější souvislost tehdejší vědecké produkce: „Typickým rysem této doby bylo, že pokud se někomu podařilo získat zajímavý titul ze zahraničí, obvykle jej vlastník využil jen pro svou informační výhodu, aby získal před ostatními náskok“ (Maňák, 2013, s. 388).
} 
cenná též reflexe transformačního pohybu v 90. letech. Karel Kosík byl jedním z mála, kdo tehdy nabourával moralizující výklad svobodě a demokracii, která zvítězila nad komunistickou diktaturou. A to nikoliv v politickém horizontu, že by se přikláněl $\mathrm{k}$ tomu či onomu systému, ale tak, že ukazoval, jak se na obou stranách prosazuje hlubší nutnost, a že řeč namísto jedněch fantazmatických mocností (,strana“) ovládly jiné (,trh“). ${ }^{22}$

Nešlo mi zde o morální poučení o zločinnosti komunistického režimu, ani o posvátnosti režimu svobody a demokracie, který ho nahradil. Když už, chtěl bych v tomto textu zůstavit poučení nikoliv morální: pokud jde o vzdělání, před nárokem myslet nás nezachrání ani komunistická strana, ani odvolávání se na svobodu a demokracii či tržní mechanismy.

\section{Literatura}

ARENDT, Hannah, 1996. Původ totalitarismu I-III. Praha: Oikoymenh. ISBN 80-86005-135 .

BAYEROVÁ, Marie, GABRIEL, Jiří, eds., 1995. Česká filozofie ve 20. století. 1., Směry, osobnosti, problémy. Brno: Filozofická fakulta Masarykovy univerzity. ISBN 80-210-1222-6.

BALÁŽ, Ondřej, 1977. Učitel' - ústredný činitel' vo výchove socialistickej osobnosti. Pedagogika. Roč. 26, č. 6, s. 653-663.

CIPRO, Miroslav, 1973. Škola - opora socialismu: výběr pedagogických statí. Praha: Státní pedagogické nakladatelství.

ENGST, Jaroslav, 1960. Socialistický humanismus a komunistická výchova. Pedagogika. Roč. 9, č. 5, s. 574-83.

FIALA, Václav, 1964. Morální vlastnosti komunistického člověka. Pedagogika. Roč. 14, č. 4, s. 440-51.

FIDELIUS, Petr, 1998. Řeč komunistické moci. Praha: Triáda. ISBN 80-86138-03-8.

GALLA, Karel, SEDLÁŘ, Richard, 1979. Úkoly výchovy v rozvíjení socialistického vědomí dětí a mládeže. Pedagogika. Roč. 28, č. 1, s. 3-10.

GRULICH, Vladimír, 1982. Marxismus-leninismus - metodologický základ pedagogické vědy. Pedagogika. Roč. 31, č. 6, s. 653-663.

HELD, Klaus, 2018. Die biblische Glaube. Phänomenologie seiner Herkunft und Zukunft. Frankfurt am Main: Vittorio Klostermann. ISBN 978-3-465-04353-9.

HUSSERL, Edmund, 1993. Krize evropských věd a transcendentální fenomenologie: úvod do fenomenologické filosofie. Praha: Academia. ISBN 80-200-0561-7.

HUSSERL, Edmund, 1993. Logische Untersuchungen. Bd. 2., Elemente einer phänomenologischen Aufklärung der Erkenntnis. Tübingen: Niemeyer. ISBN 3-484-70118-8. HUSSERL, Edmund a Michael WEILER, 2002. Natur und Geist: Vorlesungen, Sommersemester 1919. Dordrecht: Kluwer. ISBN 1-4020-0404-4.

\footnotetext{
22 Srov. např. „Na místo všemocného státu, pro něhož jsou občani poddanými a on jejich neomezeným poručníkem, nastupuje po roce 1989 jako hlavní figura zbohatlík, mění se sociální hierarchie i takzvané hodnoty. Anonymní diktatura policie a byrokracie byla vystř́íána anonymní diktaturou trhu a - trhovectvi““ (Kosík, 1997, s. 128-9).
} 
JELÍNEK, Jan, 1965. O výchově k vědeckému světovému názoru. Pedagogika. Roč. 14, č. 5, s. $570-5$.

KODÝTKOVÁ, Dagmar, 1968a. K problematice složek výchovy a jejich vymezení. Pedagogika. Roč. 17, č. 1, s. 5-21.

KODÝTKOVÁ, Dagmar, 1968b. K teorii výchovného a vzdělávacího obsahu. Pedagogika. Roč. 17 , č. 6, s. 885-893.

KOJZAR, Jaroslav, 1962. Ke vztahu politiky a výchovy. Pedagogika. Roč. 11, č. 5, s. 56271.

KOLÁ̌̌, Zdeněk, 1960. K otázce vyučovacích metod. Pedagogika. Roč. 9, č. 4, s. 678-685. KOSÍK, Karel, 1997. Předpotopní úvahy. Praha: Torst. ISBN 80-7215-036-7.

KOZEL, František, 1967. Pedagogika a její problémy ve vztahu k filosofii. Pedagogika. Roč. 16, č. 1, s. 63-79.

KUČEROVÁ, Stanislava, 1969. Hodnoty a výchova: obecné základy mravní a estetické výchovy. Praha: Krajský pedagogický ústav.

LOUKOTKA, Jiří, 1962. O výchově k vědeckému světovému názoru ve světle XXII. sjezdu a nového programu KSSS. Pedagogika. Roč. 12, č. 2, s. 129-43.

MÁCHA, Karel, 1960. K otázce poměru socialistického humanismu a komunistické výchovy. Pedagogika. Roč. 9, č. 5, s. 583-6.

MAŇÁK, Josef, 2013. Pedagogika a pedagogové v období vlády komunismu. Pedagogická orientace. Roč. 23, č. 3, s. 386-391.

MAREŠ, Jiří, 2010. O vstupování na tenký led. Pedagogika. Roč. 60, č. 2, s. 99-103.

MARX, Karl, 1978. Ekonomicko-filozofické rukopisy z roku 1844. Praha: Svoboda.

MARX, Karel a ENGELS, Bedřich, 1956. Spisy I. Praha: Státní nakladatelství politické literatury.

NOVÁK, Aleš, 2011. „Zeměkoule jakožto označení pro celek jsoucího v epoše Ge-Stell.“ In: Ročenka pro filosofii a fenomenologický výzkum. Praha: Togga, s. 95-100. ISBN 978-80-87258-87-3.

OPATA, Rudolf, ed., 1981. Nástin vývoje marxisticko-leninské pedagogiky v ČSSR. Praha: Státní pedagogické nakladatelství.

PALOUŠ, Radim, 2010. Filosofická reflexe několika pojmů školské pedagogiky. Praha: Karolinum. ISBN 978-80-246-1833-3.

PALOUŠ, Radim, 1991. K filosofii výchovy: východiska fundamentální agogiky. Praha: Státní pedagogické nakladatelství. ISBN 80-04-25390-3.

PALOUŠ, Radim, 1996. Totalismus a holismus. Praha: Karolinum. ISBN 80-7184-281-8.

PǍ̌ÍZEK, Vlastimil [Na obálce knižky je chybně uvedeno křestní jméno Vladimír - pozn. D. R.], 1984. K obsahu vzdělání a jeho soudobým přeměnám. Praha: Státní pedagogické nakladatelství.

PEŠKOVÁ, Jaroslava et al., 2010. Vybrané spisy Jaroslavy Peškové. Praha: Pro Univerzitu Karlovu v Praze, Pedagogickou fakultu vyrobilo vydavatelství a nakl. Kreace. ISBN 978-80902125-6-5. 
PRŮCHA, Jan, 2011. Vstoupit či nevstoupit na tenký led analýzy socialistické pedagogiky? Diskusní př́spěvek k úvodníku J. Mareše (Pedagogika, 2010, LX, č. 2). Pedagogika. Roč. 61, č. 2, s. 187-190. ISSN 0031-3815.

RYBÁK, David, 2019. Étos a světy dějin. Praha: Univerzita Karlova, Pedagogická fakulta. ISBN 978-80-7603-015-2.

SCHALLER, Klaus, 1993. Studie k systematické pedagogice. Praha: PedF UK. ISSN 08624461.

SEMRÁD, Jiří, 1977. Teorie výchovy, nástin jejího rozvoje a současného stavu v SSSR. Pedagogika. Roč. 26, č. 6, s. 655-667.

SKALKOVÁ, Jarmila, 1989. Aktuální problémy vědního charakteru pedagogiky. Pedagogika. Roč. 38, č. 3, s. 238-46.

SKALKOVÁ, Jarmila, 2004. Pedagogika a výzvy nové doby. Brno: Paido. ISBN 80-7315060-3.

STĘPKOWSKI, Dariusz, 2015. Emancipated Pedagogical Reason: Morality, Education and Politics in contemporary Polish moral education. Paideia. Roč. 12, č. 4, s. 1-11.

SUCHOMLINSKIJ, Vasilij Aleksandrovič, 1964. Duševný svet žiaka. Bratislava: Slovenské pedagogické nakladatel'stvo.

SYCHROVÁ, Hana, 1966. Společensky účinné vzdělání. Pedagogika. Roč. 15, č. 2, s. 65365.

URBÁŠEK, Pavel, PULEC, Jiří, 2012. Vysokoškolský vzdělávací systém v letech 1945-1969. Olomouc: Univerzita Palackého v Olomouci. ISBN 978-80-244-2979-3.

VÁŇA, Josef, 1960. Člověk jako základní kategorie marxistické pedagogiky. Pedagogika. Roč. 9, č. 6, s. 686-690.

VÁŇA, Josef, 1961. K problému teoretických základů komunistické mravní výchovy. Pedagogika. Roč. 10, č. 4, s. 425-35.

VÁŇA, Josef, 1961. O metodologických problémech v rozvoji pedagogické vědy. Pedagogika. Roč. 11, č. 3, s. 61-70.

ZOUNEK, Jiří, Michal ŠIMÁNĚ a Dana KNOTOVÁ, 2017. Normální život v nenormální době: základni školy a jejich učitelé (nejen) v období normalizace. Praha: Wolters Kluwer. ISBN 978-80-7552-709-7.

ZOUNEK, Jiří, Michal ŠIMÁNĚ a Dana KNOTOVÁ, 2017. Socialistická základní škola pohledem pamětníki̊: sonda do života učitelì v Jihomoravském kraji. Praha: Wolters Kluwer. ISBN 978-80-7552-493-5. 